\title{
A Rapid Growth of Aulacoseira granulata (Bacillariophyceae) during the Typhoon Season in the South Basin of Lake Biwa
}

\author{
Shin-ichi Nakano, Yasushi Seike, Tatsuki Sekino, Minoru Okumura, \\ Keiichi Kawabata, Kaoru Fujinaga, Masami Nakanishi, Osamu Mitamura, \\ Michio Kumagai and Hiroshi Hashitani
}

\begin{abstract}
Changes in the abundance of phytoplankton and in the concentrations of nutrients and suspended solids (SS) were followed at a sampling station in the southern basin of Lake Biwa during the Biwako Transport Experiment (BITEX'93) from 24 August to 12 September, 1993. SS concentration increased rapidly when typhoon 9313 struck the lake on 4 September. On this occasion, concentrations of dissolved nitrogen and phosphorus increased, probably due to their release from the sediment resuspended by turbulent mixing. Between 3 and 10 September, the whole water column remained homothermal and was well mixed with the Brunt-Väisälä frequency remaining at $0 \mathrm{sec}^{-1}$. The predominant phytoplankton during the BITEX period was Aulacoseira granulata. Chlorophyll concentrations and algal densities started to increase before the passage of the typhoon ( 3 September). The alga proliferated rapidly to 7 September, and this was complemented by a decrease in nitrogen and phosphorus concentrations.
\end{abstract}

Key words : Aulacoseira granulata, physical mixing, Lake Biwa, BITEX'93

\section{Introduction}

Physical processes are mainly responsible for transporting matter in lakes. The same processes transport phytoplankton to favourable or unfavourable environments, and it has been considered that such transportation influences the fate of phytoplankton. Although conceptual and theoretical models for changes in abundance, activity and species composition of phytoplankton with special reference to physical processes have been developed (REYNOLDS, 1989), lake-specific information on plankton dynamics is still limited.

Japan is often subject to typhoons during the autumn. Some of these reach the catchment of Lake Biwa $\left(35^{\circ} 10^{\prime} \mathrm{N}, 136^{\circ} 00^{\prime} \mathrm{E}\right.$, altitude $85 \mathrm{~m}$ ) and cause physical disturbance to the lake. However, information about the effect of such disturbances on phytoplankton in the lake is still scarce. We hypothesized that physical turbulence would result in destratification, or at least, an erosion of the temperature structure and an increase in the advection of nutrients into the upper water column which, in turn, would result in changes in the activity and/or species composition of phytoplankton. Two typhoons struck the catchment area of Lake Biwa during September 1993, and, following one of them, there was rapid growth of diatoms. In the present article, we described the phytoplankton dynamics in the lake during this period with special reference to physical factors and examined the reality of our hypothesis.

\section{Materials and methods}

Water samples were collected during BITEX'93 (Biwako Transport Experiment) between 24 August to 12 September, 1993 at Station S $\left(35^{\circ} 03.600^{\prime} \mathrm{N}, 135^{\circ} 54.300^{\prime} \mathrm{E}, 3.6 \mathrm{~m}\right.$ depth) in the South Basin of Lake Biwa at approximately 2-day intervals. The South Basin of Lake Biwa is $58 \mathrm{~km}^{2}$ in area and contains 27.5 $\mathrm{x} 10^{9} \mathrm{~m}^{3}$ of water. Its maximum depth is $8.0 \mathrm{~m}$, and the mean depth is $3.5 \mathrm{~m}$. Its retention time during summer is variable, depending on the discharge controlled by the Seta River Weir: about 1 week for a wet summer, and 2 weeks for 
a dry summer. The retention time during the BITEX period was about 1 week (JiAo et al., in press). Vertical water temperature was measured every $10 \mathrm{~cm}$ with a CTD profiler (F-probe, Centre for Water Research, Australia). A 3 liter VanDorn water sampler was used to collect water samples from $0.5 \mathrm{~m}$ below the surface.

On each occasion, a portion of the water sample was filtered through a precombusted $\left(430^{\circ} \mathrm{C}\right.$ for 2 hr) Whatman GF/C filter. The filtrate was used for chemical analysis, and the seston retained on the filter was analysed for particulate matter and phytoplankton pigments. Two filters for each water sample were prepared: one for suspended solids (SS), the other for chlorophyll. SS concentration was determined after drying the seston retained on the filter at $105^{\circ} \mathrm{C}$. Concentrations of chlorophyll on the filters were determined by the method of SCOR/UNESCO (1966).

Ammonium nitrogen $\left(\mathrm{NH}_{4}{ }^{+}-\mathrm{N}\right)$ was measured by the indophenol method (SAGI, 1966). Nitrite $\left(\mathrm{NO}_{2}{ }^{-}-\mathrm{N}\right)$ and nitrate nitrogen $\left(\mathrm{NO}_{3}{ }^{-} \mathrm{N}\right)$ were determined by the method of BENDSCHNEIDER and Robinson (1952) and Wood et al. (1967), respectively. Dissolved organic nitrogen (DON) was measured by the KJELDAHL-method, using $\mathrm{SeOC}_{2}$ as a catalyst. Dissolved inorganic phosphorus (DIP) was determined by the method of MuRPHY and Riley (1962), after preconcentration of phosphate (HASHITANi et al., 1987). Total dissolved phosphorus (TDP) was determined by the method of MENzel and Corwin (1965), and dissolved organic phosphorus (DOP) was calculated by subtracting DIP from TDP.

A 200-ml sample of water was fixed with acidified Lugol's solution at a final concentration of $1 \%$, and the phytoplankton samples were concentrated by natural sedimentation. Cells of phytoplankton were enumerated in a haematocytometer under a microscope.

Water density ( $\rho)$, uncorrected for solute concentration, was calculated using the sixth order equation (ZoHARY and RoBarTs, 1989) fitted to the density vs. water temperature data (HUTCHINSON, 1957).

$\rho=a+b \mathrm{~T}+c \mathrm{~T}^{6}+d \mathrm{~T}^{3}-e \mathrm{~T}^{5}-f \mathrm{~T}^{2}$ where $\rho$ is water density $\left(\mathrm{kg} \cdot \mathrm{m}^{-3}\right), \mathrm{T}$ is water temperature $\left({ }^{\circ} \mathrm{C}\right)$ and from $a$ to $f$ are constants as follows: $a=$ $9.9973 \times 10^{2} ; b=1.0785 \times 10^{-1} ; c=2.5328 \times 10^{-9}$; $d=2.3833 \times 10^{-4} ; e=1.5762 \times 10^{-7} ; f=1.3060 \times$ $10^{-2}$. Density gradient $\left(\mathrm{d} \rho / \mathrm{dz}, \mathrm{kg} \cdot \mathrm{m}^{-3} \cdot \mathrm{m}^{-1}\right)$ was determined as follows:

$$
\mathrm{d} \rho / \mathrm{dz}=\left(\mathrm{D}_{2}-\mathrm{D}_{1}\right) / \mathrm{dz}
$$

where $D_{1}$ and $D_{2}$ are water density at two different depths $(\mathrm{m})$, and $\mathrm{dz}$ is the intervals $(\mathrm{m})$ of the depths. Finally, we calculated the BruntVäisälä Ffrequency $\left(\mathrm{N}^{2}, \mathrm{sec}^{-2}\right)$ as follows:

$$
\mathrm{N}^{2}=\left(\mathrm{g} / \rho_{\mathrm{m}}\right)(\mathrm{d} \rho \mathrm{m} / \mathrm{dZm})
$$

where $\mathrm{g}\left(\mathrm{m} \cdot \mathrm{sec}^{-2}\right)$ is gravitational acceleration, $\rho$ $\mathrm{m}\left(\mathrm{kg} \cdot \mathrm{m}^{-3}\right)$ is the mean water density of the water column and $\mathrm{d} \rho \mathrm{m} / \mathrm{dzm}$ is the mean density gradient $\left(\mathrm{kg} \cdot \mathrm{m}^{-3} \cdot \mathrm{m}^{-1}\right)$ of the water column.

The data presented here are summarized in the BITEX baseline data overviews (Kumagal and NAKANO, 1996): meteorological data were derived from HaYAml et al. (1996), water temperature data from KumaGal et al. (1996), chemical data from HaSHITAN et al. (1996) and biological data from NAKANO et al. (1996).

\section{Results and discussion}

The average atmospheric temperature (Fig. 1A) was high (ca. $25^{\circ} \mathrm{C}$ ) between 24 August and 4 September, though there was a large fluctuation between 24 and 29 August. It decreased rapidly on 5 September and increased again from 7 September. The average wind speed (Fig. 1B) was relatively high $\left(>5 \mathrm{~m} \cdot \mathrm{sec}^{-1}\right)$ between 27 and 28 August. It remained low $\left(<2 \mathrm{~m} \cdot \mathrm{sec}^{-1}\right)$ from 30 August to 3 September but rapidly increased (maximum $10.8 \mathrm{~m} \cdot \mathrm{sec}^{-1}$ ) on 4 September when typhoon 9313 struck the lake. The average wind speed increased again due to typhoon 9314 which struck the lake on 8 September, and relatively a high wind speed $\left(5.7 \mathrm{~m} \cdot \mathrm{sec}^{-1}\right)$ was recorded on 9 September. Maximum insolation was high between 24 August and 5 September (ca. $10 \mathrm{MJ}$. $\left.\mathrm{m}^{-2} \cdot 6 \mathrm{~h}^{-1}\right)$, decreased rapidly to $1.6 \mathrm{MJ} \cdot \mathrm{m}^{-2} \cdot 6 \mathrm{~h}^{-1}$ on 7 September and increased again from 8 September (Fig. 1C).

From 24 August to 1 September, the thermal stratification of lake water (Fig. 2A) was weak, and the water of the upper layer $(<1.8 \mathrm{~m}$ depth, ca. $26^{\circ} \mathrm{C}$ ) seemed to be well mixed when the 


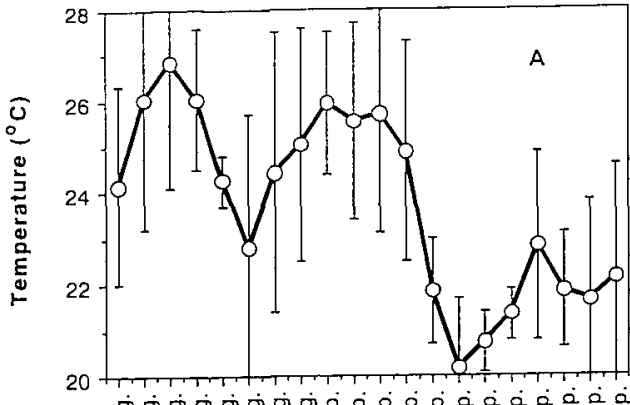

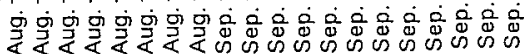

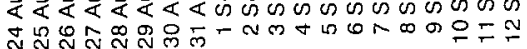

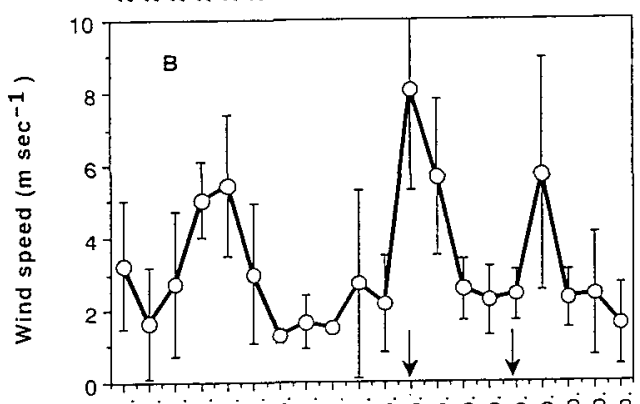

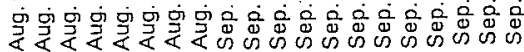

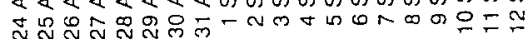

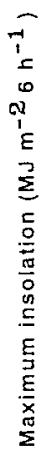

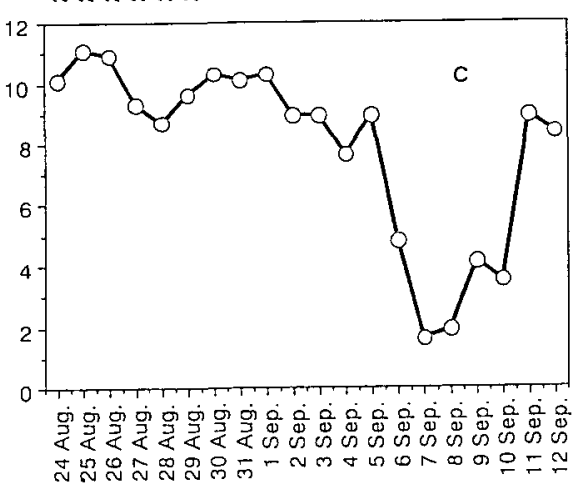

Fig. 1. Changes in the average atmospheric temperature (A), wind speed (B) and maximum insolation $(C)$ during the BITEX period. Vertical bars indicate difference between the maximum and minimum values. Arrows indicate typhoon events.

average wind speed was high between 27 and 28 August (Fig. 1B). When the highest water temperature $\left(28.1{ }^{\circ} \mathrm{C}\right)$ was recorded on 1 September, the Brunt-Väisälä frequency (Fig. 2B) also increased to the highest value of $1562 \times$ $10^{-6} \mathrm{sec}^{-2}$, indicating that thermal stratification was strongest on that occasion.

The thermal structure of lake water became almost homothermal from 3 September as typhoon 9313 approached the lake. The BruntVäisälä frequency (Fig. 2B) was $0 \mathrm{sec}^{-2}$ between 3 and 10 September, indicating that the lake was well mixed. This was due to typhoons 9313 and 9314 (Fig. 1B) and low maximum insolation (Fig. 1C). On 12 September, lake water started to thermally stratify again probably because of low wind speed (Fig. 1B) and increased insolation (Fig. 1C).

Concentrations of SS from $0.5 \mathrm{~m}$ below the surface increased slightly between $26\left(3.5 \mathrm{mg} \cdot \mathrm{l}^{-1}\right)$ and $28\left(4.5 \mathrm{mg}^{-1} \mathrm{1}^{-1}\right)$ August (Fig. 3). They increased again from 3 September $\left(4.5 \mathrm{mg} \mathrm{1}^{-1}\right)$ and reached a maximum concentration of 17.9 $\mathrm{mg} \cdot \mathrm{l}^{-1}$ on 4 September, the day when typhoon 9313 passed the study area. Thereafter, SS concentration continually decreased.

Concentrations of DIN $\left(\mathrm{NO}_{3}{ }^{-}-\mathrm{N}+\mathrm{NO}_{2}{ }^{-}-\mathrm{N}+\right.$ $\mathrm{NH}_{4}{ }^{+}-\mathrm{N}$ ) (Fig. 4A) decreased consistently between 24 August $\left(158 \mu \mathrm{gN} \cdot 1^{-1}\right)$ and 3 September $\left(31 \mu \mathrm{gN} \cdot 1^{-1}\right)$. They increased during the passage of typhoon 9313 (4 September, $104 \mu \mathrm{gN} \cdot 1^{-1}$ ), and thereafter decreased to 10 September $\left(9 \mu \mathrm{gN} \cdot \mathrm{l}^{-1}\right)$. Concentrations of DON (Fig. 4A) fluctuated greatly between 50 and $340 \mu \mathrm{gN} \cdot 1^{-1}$ during the study period, but the pattern was generally similar to that of DIN except for a large peak on 28 August $\left(339 \mu \mathrm{gN} \cdot \mathrm{I}^{-1}\right)$ and another after 5 September $\left(256 \mu \mathrm{gN} \cdot \mathrm{l}^{-1}\right)$.

DOP concentrations (Fig. 4B) decreased from 8.2 to $4.1 \mu \mathrm{gP} \cdot 1^{-1}$ during the study period with some fluctuations. DIP concentration (Fig. 4B) increased on 4 September $\left(2.5 \mu \mathrm{gP} \cdot \mathrm{I}^{-1}\right)$ and remained at a relatively high level $\left(2.1 \mu \mathrm{gP} \cdot \mathrm{I}^{-1}\right)$ on 5 September, similar to the DIN concentration, but the concentrations were mostly low $(<1.0$ $\mu \mathrm{gP} \cdot \mathrm{l}^{-1}$ ) during the study period.

Chlorophyll concentrations (Fig. 5) were relatively low $\left(<\left.5.0 \mu \mathrm{g} \cdot\right|^{-1}\right)$ between 24 August and 1 September. Unlike SS concentrations, chlorophyll concentrations did not increase significantly between 26 and 28 August. They started to increase from 3 September and reached a maximum $\left(26 \mu \mathrm{g} \cdot \mathrm{l}^{-1}\right)$ on 10 September. The predominant species of phytoplankton was Aulacoseira granulata (Bacillariophyceae). Aphanocapsa sp. (Cyanophyceae) were also 

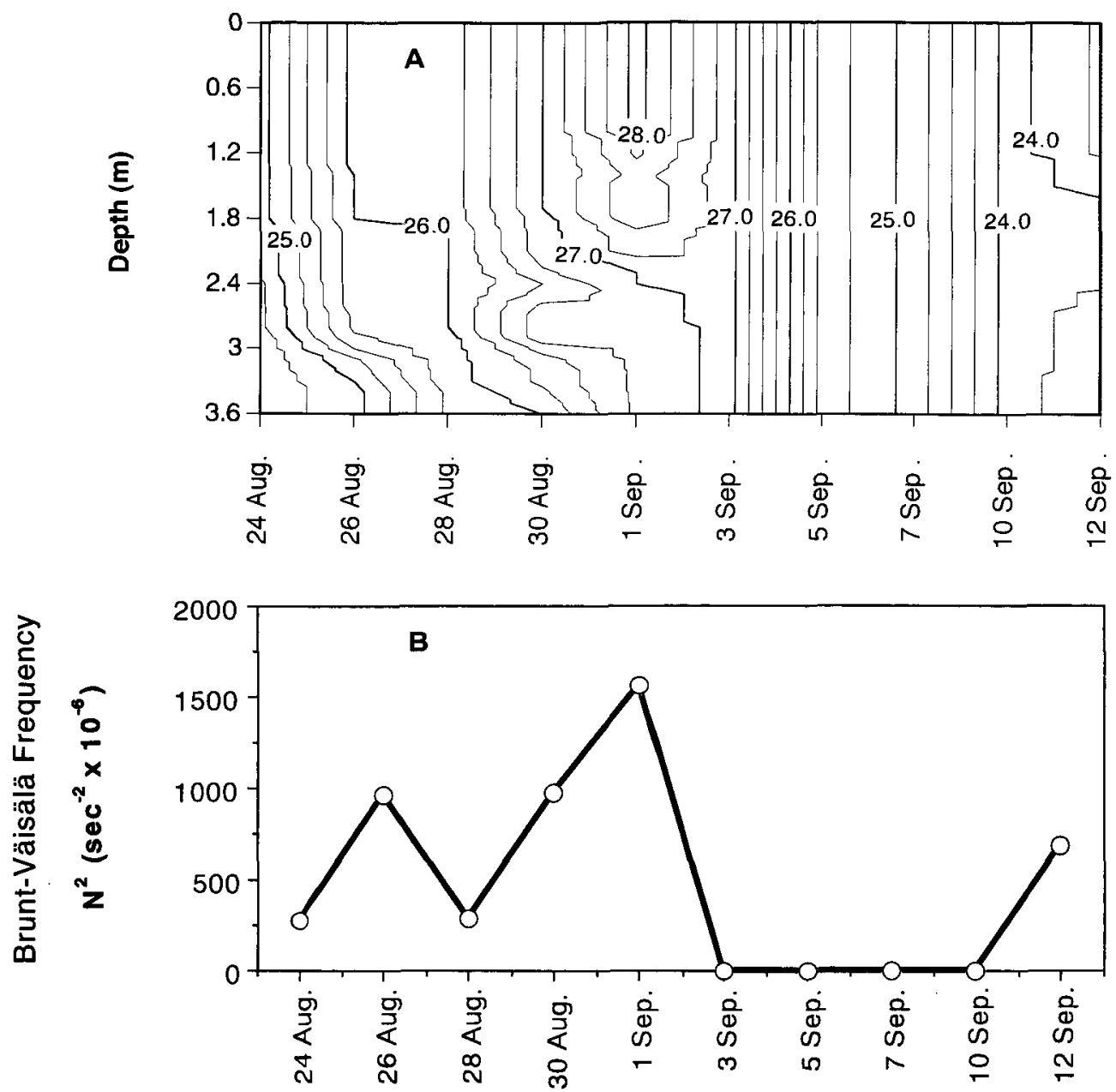

Fig. 2. Changes in thermal structure (A) and Brunt-Väisälä frequency (B) at Station $S$ during the BITEX period.

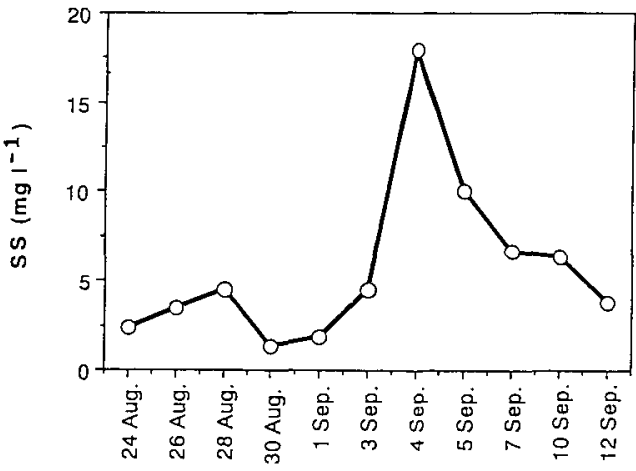

Fig. 3. Changes in concentration of suspended solids (SS) from $0.5 \mathrm{~m}$ below the surface at Station $\mathrm{S}$ during the BITEX period. frequently observed, fluctuating around 2000 cells $\mathrm{ml}^{-1}$. Abundance of this alga (ca. $3 \mu \mathrm{m}^{3} \cdot \mathrm{cell}^{-1}$ ), however, was negligible compared with that of $A$. granulata. A. granulata increased from 3 September, attained a maximum density $(375$ cells $\left.\cdot \mathrm{ml}^{-1}\right)$ on 7 September and thereafter decreased (Fig. 5).

As mentioned previously, typhoon 9313 struck the lake on 4 September, and the highest wind speed $\left(10.8 \mathrm{~m} \cdot \mathrm{sec}^{-1}\right)$ was recorded. Since lake water had already been well mixed prior to this date $\left(\mathrm{N}^{2}=0 \mathrm{sec}^{-2}\right.$, Fig. $\left.2 \mathrm{~B}\right)$, strong winds due to the typhoon probably disturbed the bottom sediment of the lake and resuspended it. In Lake Biwa, such resuspension of bottom sediment can be predicted by a model based on field observations 

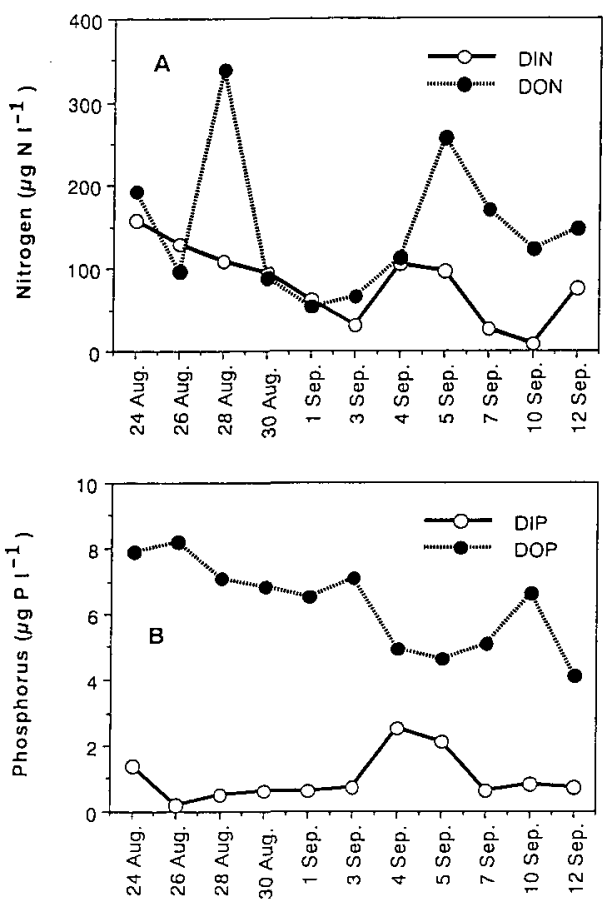

Fig. 4. Changes in concentrations of dissolved inorganic nitrogen (DIN) and organic nitrogen (DON) (A), and those of dissolved inorganic phosphorus (DIP) and organic phosphorus (DOP) (B) from 0.5 $m$ below the surface at Station $S$ during the BITEX period.

(Kumagai, 1988).

Since winds due to the typhoon blew strongly, and the Brunt-Väisälä frequency was $0 \mathrm{sec}^{-2}$, a number of phytoplankton could have been resuspended on 4 September. However, the increase in chlorophyll concentration (Fig. 5A) on this occasion was negligible compared with that on 3 September (Fig. 3). One possible explanation for the smaller increase in chlorophyll concentration is that most of the phytoplankton cells on the sediments had already been recruited to the water column through the preceding mixing on 3 September, rather than resuspended during the following turbulence associated with typhoon 9313. Thus, even without remarkable physical events such as typhoons, A. granulata in the south basin of Lake Biwa may be resuspended when lake water is destratified and mixed.

The increase in concentrations of DIN, DON
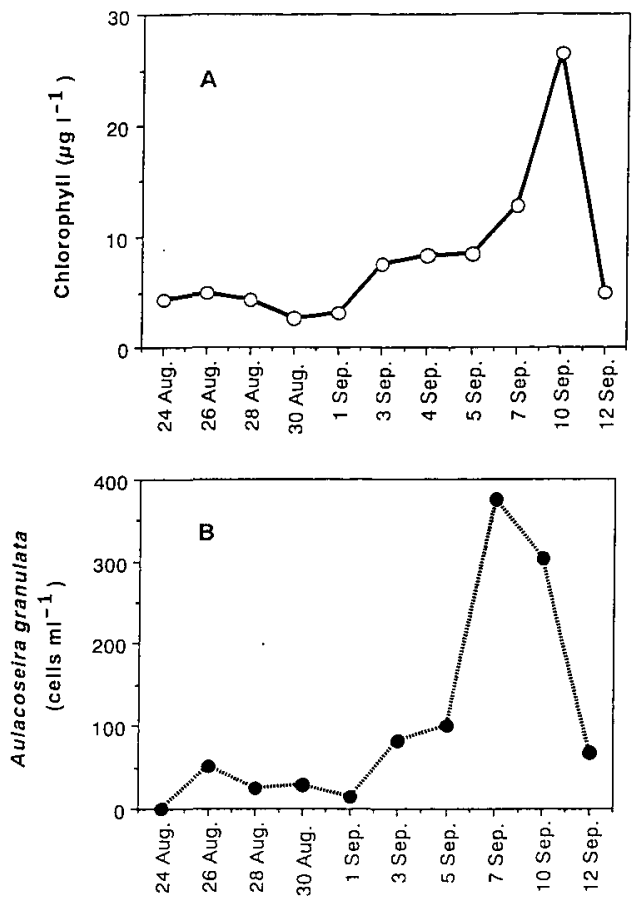

Fig. 5. Changes in concentration of chlorophyll (A) and cell density of Aulacoseira granulata (Bacillariophyceae) (B) from 0.5 $\mathrm{m}$ below the surface at Station $S$ during the BITEX period.

and DIP on 4 September (Fig. 4) were probably due to their release from the resuspended sediment. Increase of $A$. granulata was most prolific between 5 and 7 September (Fig. 5), and concentrations of DIN, DON and DIP decreased simultaneously. This was probably due to the utilization of these nutrients through the rapid growth of the alga.

Almost every year in the south basin of Lake Biwa, Uroglena americana, which causes a fresh water red tide, proliferates massively from May to mid-June. Dominant species of phytoplankton from mid-June to July are annually variable, and A. granulata dominates between August and October (Table 1). Environmental conditions during the autumn in this basin, therefore, are probably favourable to growth of this alga. Previous studies have demonstrated that growth of algae belonging to the genus Aulacoseira is turbulence-dependent: the algae needs turbulence 
Table 1. Dominant phytoplankton species in the South Basin of Lake Biwa during the warm season from 1989 to 1993.*

\begin{tabular}{|c|c|c|c|c|c|c|}
\hline & 1988 & 1989 & 1990 & 1991 & 1992 & 1993 \\
\hline \multirow[t]{2}{*}{ May } & Uroglena & Uroglena & Uroglena & Uroglena & Uroglena & Uroglena \\
\hline & Stephanodiscus & & & & & \\
\hline \multirow[t]{2}{*}{ June } & Uroglena & Uroglena & Aulacoseira & Uroglena & Uroglena & Closterium \\
\hline & & Stephanodiscus & Chloococcus & & Aulacoseira & Aulacoseira \\
\hline \multirow[t]{2}{*}{ July } & Schroederia & Stephanodiscus & Dichotomococcus & Stephanodiscus & Closterium & Stephanodiscus \\
\hline & & Cyclotella & Aulacoseira & Aulacoseira & Aulacoseira & Cyclotella \\
\hline \multirow[t]{2}{*}{ August } & Stephanodiscus & Aulacoseira & Cyclotella & Aulacoseira & Aulacoseira & Aulacoseira \\
\hline & & & Coelastrum & & & \\
\hline \multirow[t]{2}{*}{ September } & Aulacoseira & Stephanodiscus & Coelastrum & Aulacoseira & Coelastrum & Aulacoseira \\
\hline & & & Aulacoseira & & Aulacoseira & \\
\hline October & Aulacoseira & Aulacoseira & Aulacoseira & Aulacoseira & Aulacoseira & Aulacoseira \\
\hline
\end{tabular}

*Data were collected by the Shiga Prefectural Institute of Public Health and Environmental Science (1991 and 1995).

to maintain its position in the euphotic zone because of their high specific gravity (LunD, 1954; Petrova, 1986). Net changes in abundance of Aulacoseira is mainly determined by the balance between the rates of sinking loss and resuspension (Reynolds et al., 1986). Turbulence-dependent growth of $A$. granulata is also likely in the south basin of Lake Biwa (Miyajima et al., 1994).

In the present study, we followed a series of processes which supported our hypothesis that the growth of this alga was stimulated by the passage of a typhoon which suspended sediment and consequently increased the concentration of biologically available nutrients.

\section{Acknowledgments}

We thank Drs. T. NAGATA and W. F. VinCENT for coordinating the core program in BITEX'93. Thanks are also due to the crew of R/V Hakken for assistance on shipboard. The authors would like to thank Messrs. T. SATo, S. Ueda and A. Nagashima for their assistance with the field surveys and to all the other members of the Laboratory of Environmental Analytical Chemistry, Shimane University, for their assistance in conducting the analysis of water samples, and to Ms. Yuko FujIsawa for counting phytoplankton cells. We are very grateful to two anonymous referees and Dr. R. D. RoBarTs for their constructive comments on the manuscript.

\section{References}

BendsChNeider, K. and R. J. Robinson (1952) : A new spectrophotometric method for the determination of nitrite in sea water. J. Mar. Res., $11: 87-96$.

Hashitani, H., M. Okumura and K. Fujinaga (1987) : Preconcentration method for phosphate in water using activated carbon loaded with zirconium. Fresenius z Anal. Chem., 326: 540-542.

Hashitani, H., Y. Seike, M. Okumura, A. Hirayama and M. Kumagai (1996): Temporal and Spatial Distribution of Nutrients and Chlorophyll $a$ during BITEX'93, p115-128. 
In Baseline Data Overviews of BITEX'93, M. Kumagai and S. Nakano (eds.) : Lake Biwa Stu. Monogr.

Hayami, Y., T. Fujiwara, W. SaKamoto, S. Endoh, Y. Okumura, Y. Azuma and M. Kumagai (1996) : Physical Limnology and Meteorological Conditions for Lake Biwa during BITEX' 93, In Baseline Data Overviews of BITEX'93, p19-32. M. Kumagai and S. Nakano (eds.) : Lake Biwa Stu. Monogr.

Hutchinson, G. E. (1957) : A Treatise of Limnology, Vol. 1 Geography, Physics, and Chemistry. Wiley, New York.

JAA, C., M. KumaGal and Y. HAYAMI (1996) : Water Balance in the South Basin of Lake Biwa, p33-64. In Baseline Data Overviews of BITEX'93, Kumagai M. and S. NaKano (eds.) : Lake Biwa Stu. Monogr.

Kumagai, M. (1988) : Predictive model for resuspension and deposition of bottom sediment in a lake. Jpn. J. Limnol., $49:$ 185-200.

Kumagai, M. and S. Nakano (eds.) (1996) : Baseline Data Overviews of BITEX'93, Lake Biwa Stu. Monogr.

Kumagai, M., C. Shimoda, W. F. Vincent and T. NaGATA (1996) : Fine scale profiling at core stations, p 91-114. In Baseline Data Overviews of BITEX'93, M. Kumagal and S. NaKano (eds.) : Lake Biwa Stu. Monogr., 91-114.

Lund, J. W. G. (1954) : The seasonal cycle of the plankton diatom Melosira italica subsp. subarctica O. Mull. J. Ecol., 42 : 151-179.

Menzel, D. W. and N. Corwin (1965): The measurement of total phosphorus in seawater based on the liberation of organically bound fraction by persulfate oxidation. Limnol. Oceanogr., $10: 280-283$.

Miyajima, T., M. Nakanishi, S. Nakano and Y. TezuKA (1994) : An autumnal bloom of the diatom Melosira granulata in a shallow eutrophic lake: physical and chemical constraints on its population dynamics. Arch. Hydrobiol., 130 : 143-162.

Murphy, J. and J. P. Riley (1962) : A modified single solution method for the determination of phosphate in natural waters. Anal. Chim. Acta, $27:$ 31-36.

Nakano, S., T. Sekino, K. Kawabata, O. Mitamura and M. Nakanishi(1996): Spatial and Temporal Changes in Abundance of Phytoplankton, p133-146. In Baseline Data Overviews of BITEX'93, KumagaI M. and S. Nakano (eds.) : Lake Biwa Stu. Monogr., 133-146.

Petrova, N. A. (1986): Seasonality of Melosira -plankton of the great northern lakes. Hydrobiologia, 138: 65-73.

Reynolds, C. S. (1989) : Physical determinants of phytoplankton succession, p9-56. In U. Sommer (ed.), Plankton ecology : succession in plankton communities. Brock/Springer Series in Contemporary Bioscience.

Reynolds, C. S., V. Montecino, M. E. Graf and S. CABrera (1986) : Short-term dynamics of a Melosira population in the plankton of an impoundment in central Chile. J. Plankton Res., 8 : 715-740.

SAGI, T. (1966) : Determination of ammonia in sea water by the indophenol method and its application to the coastal and off-shore waters. Oceanogr. Mag., 18 : 43-51.

SCOR/UNESCO Working group 17 (1966) : Determination of photosynthetic pigments in sea water. UNESCO, 69pp.

Shiga Prefectural Institute of Public Health And Environmental Science (1991 and 1995) : Data compilation of phytoplankton in Lake Biwa, 4 and 5 (in Japanese).

Wood, E. D., F. A. J. Armstrong and F. A. RichARDS (1967) : Determination of nitrate in sea water by cadmium-copper reduction to nitrite. J. Mar. Biol. Ass. U. K., 47 : 23-31.

Zohary T. and R. D. Robarts (1989) : Diurnal mixed layers and the long-term dominance of Microcystis aeruginosa. J. Plankton Res., $11: 25-48$.

(Authors : Shin-ichi NaKano ${ }^{*}$, Yasushi SEIKE2 ${ }^{2}$, Tatsuki Sekino ${ }^{3}$, Minoru Okumura ${ }^{2}$, Keiichi Kawabata $^{4}$, Kaoru FujInAGa ${ }^{2}$, Masami NaKanishi ${ }^{3}$, Osamu Mitamura ${ }^{5}$, Michio Kumagal ${ }^{1}$ and Hiroshi Hashitani ${ }^{2}$; 'Lake Biwa Research Institute, 1-10 Uchide-hama, Otsu, Shiga 520, Japan ( ${ }^{*}$ present address : Department of Agriculture, Ehime University, 3-5-7 Tarumi, Matsuyama, Ehime 790, Japan) ; ${ }^{2}$ Faculty of 
Science, Shimane University 1060 Nishikawazucho, Matsue, Shimane 690, Japan ,2* present address : Meteorology and Limnology Laboratory, Higashihonmachi 5-7-402, Matsue, Shimane 690, Japan ; ${ }^{3}$ Center for Ecological Research, Kyoto University, 4-1-23 Shimosakamoto, Otsu, Shiga 520, Japan; ${ }^{4}$ Faculty of Education, Kanazawa University, Kakumacho, Kanazawa, Ishikawa 920, Japan; ${ }^{5}$ Division of Natural Sciences, Osaka Kyoiku University, Kashiwara, Osaka 582, Japan.

Received : 31 October 1995

Accepted : 7 February 1996 